Tropical Journal of Pharmaceutical Research April 2011; 10 (2): 161-168

(C) Pharmacotherapy Group,

Faculty of Pharmacy, University of Benin,

Benin City, 300001 Nigeria.

All rights reserved.

Research Article

Available online at http://www.tjpr.org

\title{
Inhibition of Lipopolysaccharide-Induced iNOS, COX- 2, and TNF- $\alpha$ Expression by Aqueous Extract of Orixa Japonica in RAW 264.7 Cells via Suppression of NF- KB Activity
}

\section{Chang-Hee Kang ${ }^{1}$, Yung ${\text { H } \text { Choi }^{2} \text {, II-Whan Choi }}^{3}$, Jae-Dong Lee $^{4}$ and Gi-Young Kim ${ }^{1, *}$}

${ }^{1}$ Laboratory of Immunobiology, Department of Marine Life Sciences, Jeju National University, Jeju 690-756,

${ }^{2}$ Department of Biochemistry, College of Oriental Medicine, Dongeui University, Busan 614-054,

${ }^{3}$ Department of Microbiology, Inje University College of Medicine, Busan 614-735, ${ }^{4}$ Department of Microbiology, College of Natural Sciences, Pusan National University, Busan 609-735, Republic of Korea

\begin{abstract}
Purpose: To investigate the anti-inflammatory effects of aqueous extract of Orixa japonica (AEOJ) in lipopolysaccharide (LPS)-stimulated RAW 264.7 cells.

Methods: The expression of mRNA and protein using RT-PCR and Western blot analysis was investigated. The level of nitric oxide (NO) production was analyzed using Griess reaction. Release of prostaglandin $E_{2}\left(P G E_{2}\right)$ and tumor necrosis factor- $\alpha$ (TNF- $\alpha$ ) was determined using sandwich ELISA.

Results: AEOJ potently inhibited the production of nitric oxide (NO), prostaglandin $E_{2}\left(P G E_{2}\right)$, and tumor necrosis factor- $\alpha$ (TNF- $\alpha$ ) in LPS-stimulated RAW 264.7 cells. Consistent with these findings, AEOJ was also found to significantly reduce LPS-induced expression of inducible NO synthase (iNOS), cyclooxygenase-2 (COX-2), and TNF- $\alpha$ at the transcriptional level. Additionally, AEOJ attenuated LPS induced NF-KB activity via the inhibition of IKB phosphorylation and degradation. It was also found that the NF-KB inhibitor N-acetyl cysteine (NAC) attenuated LPS-induced gene expression of iNOS, COX-2, and TNF- $\alpha$. These results indicate that AEOJ attenuates LPS-induced inflammatory mediators such as $N O, P G E_{2}$, and TNF- $\alpha$ via suppression of NF-KB activity.

Conclusion: These results suggest that AEOJ has a potential activity to alleviate LPS-induced inflammation.
\end{abstract}

Keywords: Orixa japonica, Nitric oxide, Prostaglandin $E_{2}$, Tumor necrosis factor- $\alpha$, Nuclear factor- $K B$ 


\section{INTRODUCTION}

Orixa japonica is a plant that is widely distributed in East Asia. Its aqueous extract AEOJ has been used traditionally for the treatment of cough, arthritis, dysentery, and malaria [1-3]. Sharma and his colleagues also reported that AEOJ is a good pharmaceutical candidate for the treatment of obesity caused by high fat-diet [4]. More recently, it was found that AEOJ significantly inhibits the growth of acne-inducing pathogenic bacteria, is not cytotoxic to the human cell line, and suppresses acneinducing inflammatory cytokines in THP-1 cells [5]. However, little is known about the mechanism by which AEOJ inhibits lipopolysaccharide (LPS)-induced inflammation.

Inflammation is typified by the activation of immunocytes such as monocytes and macrophages, and the secretion of inflammatory mediators such as nitric oxide (NO), prostaglandin $\mathrm{E}_{2}\left(\mathrm{PGE}_{2}\right)$, and tumor necrosis factor- $\alpha$ (TNF- $\alpha$ ). Although NO plays a significant role in host immune defense, vascular regulation, neurotransmission, and other systems under normal conditions, aberrant NO expression is thought to cause severe inflammatory disease $[6,7]$. Overproduction of inducible NO synthase (iNOS) is especially related to various human diseases such as inflammatory and neuronal disorders because of the upregulation of $\mathrm{NO}$ $[8,9]$. $\quad \mathrm{PGE}_{2}$, which is derived from cyclooxygenase-2 (COX-2) by inflammatory stimulants, is also thought to be involved in the pathogenesis of some inflammatory diseases $[10,11]$. Additionally, TNF- $\alpha$ is highly expressed in macrophages involved in the inflammatory process and causes severe tissue damage, septic shock, atherosclerosis, and systemic inflammatory response syndrome $[12,13]$. Therefore, the inhibition of these inflammatory mediators would be an effective therapeutic approach for regulating LPS-induced septic shock.
$\mathrm{NF}-\mathrm{KB}$ is a nuclear transcription factor that regulates various genes related to immune and inflammatory responses, cell proliferation, growth, cell adhesion, and survival [14-15]. It is well known that NF-KB regulates the expression of inflammatory genes such as iNOS, COX-2, and TNF- $\alpha$ in order to boost inflammatory responses in early stages [16]. Previous studies also demonstrated that the inhibition of NF-kB activity may be useful for attenuating various inflammatory diseases including rheumatoid arthritis, septic shock and ischemia [17-19]. Therefore, effective inhibitors of NF-KB may explain its immunomodulatory and antiinflammatory effects in LPS-induced inflammation.

In the present study, an effort was made to show that AEOJ significantly inhibited the expression of iNOS, COX-2, and TNF- $\alpha$, and their main products via the suppression of NF-KB activity.

\section{EXPERIMENTAL}

\section{Preparation of plant extract (AEOJ)}

O. Japonica was purchased from a local oriental herb store, Kwang Myoung Dang (Busan, Republic of Korea) in February 2005, and authenticated by Professor WS Ko, College of Oriental Medicine, Dongeui University, Busan, Republic of Korea. A voucher specimen was deposited at the Department of Oriental Medicine, Dongeui University. The plant material $(100 \mathrm{~g})$ was percolated with distilled water at $100{ }^{\circ} \mathrm{C}$ for 2 h. The extract was filtered through $0.45 \mu \mathrm{m}$ filter and the filtrate freeze-dried. The extract yield was approximately $4.1 \mathrm{~g}$ and the extract (AEOJ) was kept at $4{ }^{\circ} \mathrm{C}$ until used. The extract was dissolved in phosphate buffered saline (PBS) at $1 \mathrm{mg} / \mathrm{ml}$ and filtered through $0.22 \mu \mathrm{m}$ filter before use.

\section{Reagents}

LPS and 3-(4,5-dimethylthiazol-2-yl)-2,5diphenyl-tetrazolium bromide (MTT) were 
purchased from Sigma Chemical Co. (St. Louis, MO, USA). Rabbit anti-human antibodies against iNOS, COX-2, p65, I $\mathrm{kB} \alpha$, and phospho $(p)-1 \kappa B \alpha$ were purchased from Santa Cruz Biotechnology (Santa Cruz, CA, USA). The antibody against $\beta$-actin was obtained from Sigma. Peroxidase-labeled goat anti-rabbit immunoglobulin was purchased from KOMA Biotechnology (Seoul, Republic of Korea). Dulbecco's modified Eagle's medium (DMEM) and fetal bovine serum (FBS) were obtained from WelGENE Inc. (Daegu, Republic of Korea). Other chemicals were purchased from Sigma.

\section{Cell Culture and viability}

RAW 264.7 murine macrophages cell line was kindly obtained from SJ Jeong (Kyung Hee University, Seoul, Republic of Korea) and cultured at $37{ }^{\circ} \mathrm{C}$ in $5 \% \mathrm{CO}_{2}$ in DMEM medium supplemented with $10 \%$ FBS and antibiotics (WelGENE). For the analysis of cell viability, the cells were incubated with the indicated concentrations of AEOJ for $1 \mathrm{~h}$ prior to the treatment with LPS $(1 \mu \mathrm{g} / \mathrm{ml})$ for $24 \mathrm{~h}$. Cell viability was determined by MTT assay.

\section{Isolation of total RNA and RT-PCR}

Total RNA was extracted from RAW 264.7 cells using Trizol reagent (Invitrogen, Carlsbad, USA) according to the manufacturer's instruction. One microgram of RNA was reverse-transcribed using MMLV reverse transcriptase (Bioneer, Daejeon, Republic of Korea). Then, cDNA was amplified by PCR using specific primer iNOS (forward 5'-cct cct cca ccc tac caa gt-3' and reverse 5'-cac cca aag tgcttc agt ca-3'), COX2 (forward 5'-aag act tgc cag gct gaa ct-3' and reverse 5'-ctt ctg cag tcc agg ttc aa-3'), TNF-a (forward 5'-gcg acg tgg aac tgg cag aa-3' and reverse 5'-tcc atg ccg ttg gcc agg ag-3') and $\beta$-actin (forward 5'-tgt gat ggt ggg aat ggg tca g-3' and reverse 5'-ttt gat gtc acg cac gat ttc c-3'). The following PCR conditions were applied: COX-2 and iNOS, 25 cycles of denaturation at $94{ }^{\circ} \mathrm{C}$ for $30 \mathrm{~s}$, annealing at $59{ }^{\circ} \mathrm{C}$ for $30 \mathrm{~s}$ and extended at $72{ }^{0} \mathrm{C}$ for $30 \mathrm{~s}$; $\beta$-actin, 23 cycles of denaturation at $94{ }^{\circ} \mathrm{C}$ for $30 \mathrm{~s}$, annealing at $57{ }^{\circ} \mathrm{C}$ for $30 \mathrm{~s}$ and extended at $72{ }^{\circ} \mathrm{C}$ for $30 \mathrm{~s}$. $\beta$-actin was used as an internal control to evaluate relative expression of COX-2, iNOS and TNF- $\alpha$.

\section{Western blot analysis}

Total cell extracts were prepared using PROPREP protein extraction solution (iNtRON Biotechnology, Sungnam, Republic of Korea). Cell lysates were centrifuged at $14,000 \mathrm{~g}$ at 4 ${ }^{0} \mathrm{C}$ for $10 \mathrm{~min}$ to obtain the supernatants. Supernatants were collected and protein concentrations determined using a Bio-Rad protein assay kit (Bio-Rad, Hercules, CA, USA). Samples were stored at $-80^{\circ} \mathrm{C}$ or immediately used for Western blot analysis. The proteins were separated on SDSpolyacrylamide gels and transferred to nitrocellulose membranes (Schleicher \& Schuell, Keene, NH, USA). Proteins were detected using an enhanced chemiluminescence detection system (Amersham, Arlington Heights, IL, USA).

\section{NO Assay}

RAW 264.7 cells $\left(2 \times 10^{5}\right.$ cells $\left./ \mathrm{ml}\right)$ were plated onto 24-well plates and pretreated with the indicated concentrations of AEOJ for $1 \mathrm{~h}$ prior to stimulation with $1 \mu \mathrm{g} / \mathrm{ml}$ of LPS for 24 h. Briefly, the sample supernatants were mixed with equal volume of Griess reagent ( $1 \%$ sulfanilamide in $5 \%$ phosphoric acid and $0.1 \%$ naphthylethylenediamine dihydrochloride) and then incubated at room temperature for $10 \mathrm{~min}$. The absorbance was measured at $540 \mathrm{~nm}$ on a microplate reader (Thermo Electron Corporation, Marietta, OH, USA). Nitrite concentration was determined using a dilution of sodium nitrite as a standard.

\section{Measurement of TNF- $\alpha$ and PGE $_{2}$}

The expression levels of TNF- $\alpha$ and $\mathrm{PGE}_{2}$ were measured by enzyme-linked immunosorbent assay (ELISA) kit (R\&D Systems, Minneapolis, MN, USA) according to the manufacturer's instructions. Briefly, RAW 264.7 cells $\left(2 \times 10^{5}\right.$ cells $\left./ \mathrm{ml}\right)$ were plated in 
24-well plates and pretreated with the indicated concentrations of AEOJ for $1 \mathrm{~h}$ prior to stimulation with $1 \mu \mathrm{g} / \mathrm{ml}$ of LPS for $24 \mathrm{~h}$. One hundred microliters of culture-medium supernatants were collected for the determination of $\mathrm{PGE}_{2}$ and TNF- $\alpha$ concentrations by ELISA.

\section{Statistical analysis}

All data were derived from at least three independent experiments. Statistical analyses were conducted using SigmaPlot software (version 6.0) Values were presented as mean \pm SD. Significant differences between the groups were determined using the unpaired Student's $t$-test. Statistical significance was set at $p<0.05$.

\section{RESULTS}

\section{AEOJ is not cytotoxic to RAW 264.7 cells}

To assess the effects of AEOJ on the viability of RAW 264.7 cells, we treated cells with the indicated concentrations of AEOJ in the presence or absence of LPS for $24 \mathrm{~h}$ and analyzed cell viability by MTT assay. The viability of RAW 264.7 cells was not significantly altered by 24-h incubation with up to $2 \mathrm{mg} / \mathrm{ml}$ of AEOJ (Fig 1). Additionally, in the presence of LPS $(1 \mu \mathrm{g} / \mathrm{ml})$, AEOJ did not affect the viability of the cells. Therefore, in subsequent experiments, the concentration of AEOJ used was $2 \mathrm{mg} / \mathrm{ml}$.

\section{AEOJ suppresses the expression of iNOS and NO}

To investigate whether AEOJ regulates NO production, cells were pretreated with AEOJ for $1 \mathrm{~h}$ before treatment with LPS for $24 \mathrm{~h}$, and NO production was measured by performing the Griess reagent assay. NO production was reflected in the accumulation of nitrite in the cell culture medium. Treatment with LPS resulted in significant upregulation of nitrite production (17.3 \pm 0.5 $\mu \mathrm{M})$, compared to the untreated control $(6.2 \pm$ $0.4 \mu \mathrm{M}$; Fig 2A). However, RAW 264.7 cells pretreated with AEOJ displayed a marked decrease in the induction of nitrite $(9.4 \pm 0.3$ $\mu \mathrm{M})$ after stimulation with LPS. Next, we investigated whether AEOJ regulates iNOS expression at the protein and gene levels. Consistent with the suppression of nitrite production, AEOJ induced dose-dependent downregulation of iNOS expression at the protein (Fig 2B) and gene levels (Fig 2C). These data indicate that AEOJ attenuates the upregulation of LPS-induced NO production by suppressing iNOS at the transcriptional level.

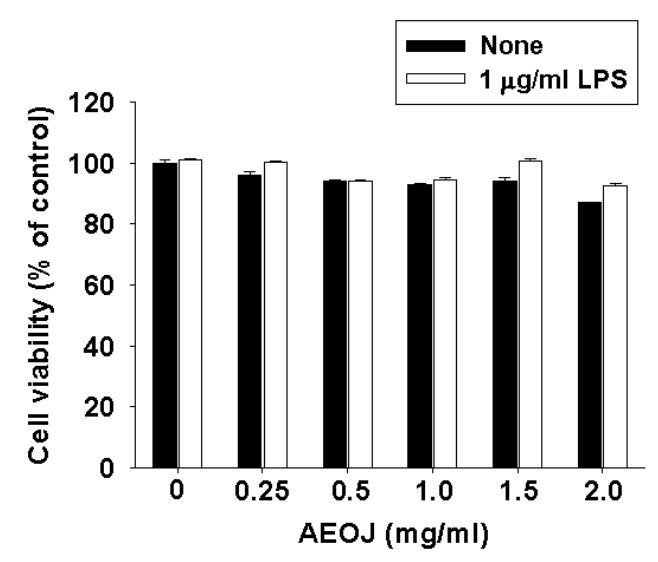

Figure 1: Effect of AEOJ on the viability of RAW 264.7 macrophage cells. Cells $\left(2 \times 10^{5}\right.$ cells $\left./ \mathrm{ml}\right)$ were incubated with the indicated concentrations of AEOJ for $1 \mathrm{~h}$ before treatment with LPS $(1.0 \mu \mathrm{g} / \mathrm{ml})$ for $24 \mathrm{~h}$. Cell viability was determined by MTT assay. Each value indicates the mean $\pm S D$ and is representative of results obtained from 3 independent experiments.

\section{AEOJ suppresses the expression of COX-2 and $\mathrm{PGE}_{2}$}

To determine whether AEOJ suppresses the production of $\mathrm{PGE}_{2}$ in LPS-stimulated RAW 264.7 cells, cells were stimulated with LPS and the amount of $\mathrm{PGE}_{2}$ secreted was measured using anti-PGE $\mathrm{E}_{2}$-coated ELISA plates. RAW 264.7 cells stimulated with LPS significantly increased the amount of $P \mathrm{PE}_{2}$ secreted (4826 \pm $123 \mathrm{pg} / \mathrm{ml}$ ) as compared to untreated controls $(145 \pm 23 \mathrm{pg} / \mathrm{ml}$; Fig 3A); however, this induction was markedly suppressed in AEOJtreated cells $(1978 \pm 98 \mathrm{pg} / \mathrm{ml})$. Next, we confirmed the expression of COX-2 in RAW 264.7 cells by Western blot analysis and RTPCR. Treatment with AEOJ decreased LPSinduced COX-2 expression at the protein level 
in a dose-dependent manner (Fig 3B). Additionally, RT-PCR data showed that the mRNA expression of COX-2 was increased by LPS treatment; however, pretreatment with AEOJ reversed LPS-induced COX-2 mRNA expression in RAW 264.7 cells. These data indicate that AEOJ suppresses the upregulation of LPS-stimulated $\mathrm{PGE}_{2}$ expression via the suppression of COX-2 expression at the transcriptional level.

(A)

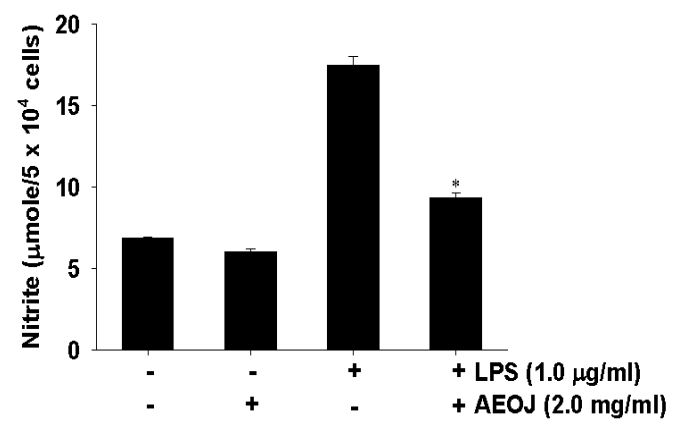

(B)

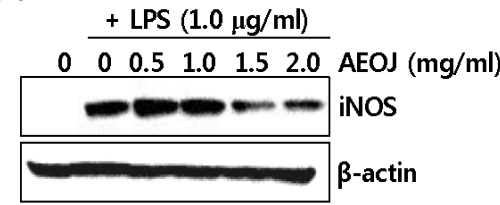

(C)

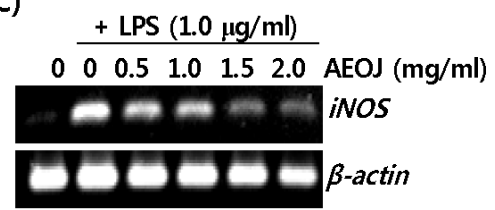

Figure 2: Effect of AEOJ on the inhibition of LPSinduced NO and iNOS. (A) Cells $\left(2 \times 10^{5}\right.$ cells $\left./ \mathrm{ml}\right)$ were incubated with the indicated concentrations of $A E O J$ for $1 \mathrm{~h}$ before treatment with LPS $(1.0 \mu \mathrm{g} / \mathrm{ml})$ for $24 \mathrm{~h}$. (A) The amounts of NO were determined using the Griess reagent in the culture medium. ${ }^{*} P<0.01$ is significantly different from the value in cells treated with LPS treatment alone. (B) In a parallel experiment, equal amounts of cell lysate were resolved on SDSpolyacrylamide gels, transferred to nitrocellulose membranes, and probed with antibodies against iNOS. (C) Total RNA was isolated, and RT-PCR analyses of iNOS were performed. $\beta$-Actin was used as an internal control for Western blot analysis and RT-PCR. The experiment was carried out in triplicate, and the mean was taken.

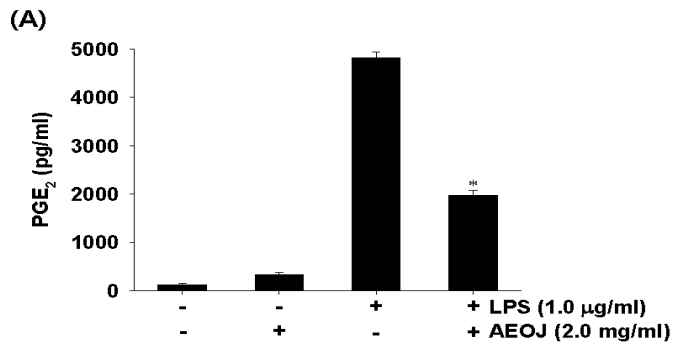

(B)

$$
+\operatorname{LPS}(1.0 \mu \mathrm{g} / \mathrm{ml})
$$

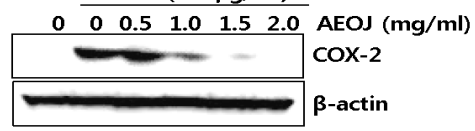

(C)

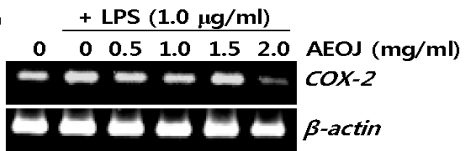

Figure 3: Effect of AEOJ on the inhibition of LPSinduced $\mathrm{PGE}_{2}$ and COX-2. (A) Cells $\left(2 \times 10^{5}\right.$ cells $\left./ \mathrm{ml}\right)$ were incubated with the indicated concentrations of AEOJ for $1 \mathrm{~h}$ before treatment with LPS $(1.0 \mu \mathrm{g} / \mathrm{ml})$ for $24 \mathrm{~h}$. (A) The amount of $\mathrm{PGE}_{2}$ was determined using a specific enzyme immunoassay performed according to the manufacturer's instructions. ${ }^{\star} P<0.01$ is significantly different from the value in cells treated with LPS treatment alone. (B) In a parallel experiment, equal amounts of cell lysates were resolved on SDSpolyacrylamide gels, transferred to nitrocellulose membranes, and probed with antibodies against COX-2. (C) Total RNA was isolated, and RT-PCR analyses of COX-2 were performed. $\beta$-Actin was used as an internal control for Western blot analysis and RT-PCR. The experiment was carried out in triplicate, and the mean was taken.

\section{AEOJ inhibits production of TNF- $\alpha$ at the gene level}

Next, we attempted to test the potential effects of AEOJ on the mRNA expression and secretion of TNF- $\alpha$ in LPS-stimulated RAW 264.7 cells. Cells were pretreated with $2 \mathrm{mg} / \mathrm{ml}$ AEOJ for $1 \mathrm{~h}$ before treatment with LPS for $24 \mathrm{~h}$. TNF- $\alpha$ production was assessed in the culture supernatant by ELISA. TNF- $\alpha$ was slightly expressed in untreated controls $(1091 \pm 78 \mathrm{pg} / \mathrm{ml})$. However, LPS stimulation significantly increased TNF- $\alpha$ secretion at $24 \mathrm{~h}$ (4826 \pm $156 \mathrm{pg} / \mathrm{ml}$; Fig 4A). Pretreatment with AEOJ significantly suppressed LPS-induced TNF-a secretion $(2430 \pm 57 \mathrm{pg} / \mathrm{ml})$, even though 
AEOJ itself did not alter the release of TNF- $\alpha$ in the absence of LPS. To evaluate whether the downregulation of AEOJ-induced TNF- $\alpha$ release was due to the regulation of the TNFa gene in LPS-stimulated RAW 264.7 cells, we performed RT-PCR analysis at $6 \mathrm{~h}$ after treatment with LPS. AEOJ reduced LPSinduced expression of TNF- $\alpha$ mRNA in a dose-dependent manner (Fig 4B). These data indicate that AEOJ suppressed LPSstimulated TNF- $\alpha$ release at the transcriptional level.

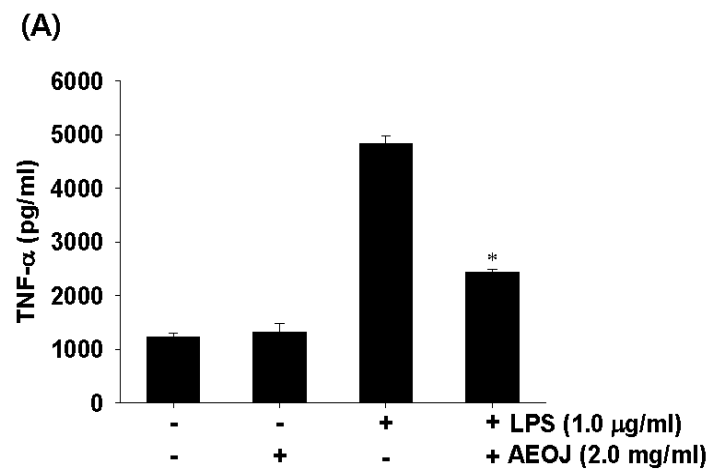

(B)

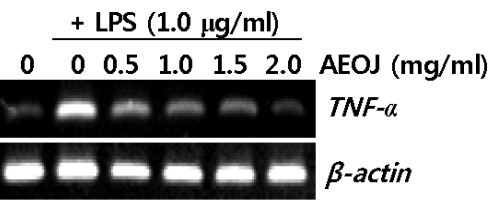

Figure 4: Effect of AEOJ on LPS-induced TNF- $\alpha$ expression in RAW 264.7 cells. Cells $\left(2 \times 10^{5}\right.$ cells $\left./ \mathrm{ml}\right)$ were incubated with the indicated concentrations of AEOJ for $1 \mathrm{~h}$ before treatment with LPS $(1.0 \mu \mathrm{g} / \mathrm{ml})$ for 6 $\mathrm{h}$ or $24 \mathrm{~h}$. (A) After incubation for $24 \mathrm{~h}$, the supernatant was collected, and the amount of TNF- $\alpha$ was measured by ELISA. (B) In a parallel experiment, the mRNA expression level of TNF- $\alpha$ was determined by RT-PCR analysis that was carried out $6 \mathrm{~h}$ after treatment with LPS. $\beta$-Actin was used as an internal control for RTPCR. The experiment was carried out in triplicate, and the mean was taken.

\section{AEOJ attenuates the expression of inflammatory mediator gene products via the suppression of NF-kB activity}

Because it is well known that NF-kB activation by LPS induces the expression of inflammatory mediators such as iNOS, COX2 , and TNF- $\alpha$, we performed Western blot analysis to investigate whether AEOJ regulates NF-KB activity. Because the translocation of NF-KB into the nucleus is preceded by the phosphorylation and degradation of the IKB protein, we analyzed the expression of $1 \mathrm{kB}, \mathrm{p}-\mathrm{IKB}_{\mathrm{K}}$, and p65 in the cytosol. AEOJ inhibits LPS-induced degradation and phosphorylation of IKB (Fig 5A). In addition, AEOJ helped sustain p65 expression in the cytosol. In order to test whether NF-KB induces iNOS, COX-2, and TNF- $\alpha$ expression, we treated cells with a non-cytotoxic concentration of NAC, an NF$\mathrm{KB}$ inhibitor, and performed RT-PCR to check the expression of inflammatory mediator gene products. NAC significantly reversed LPS-induced iNOS, COX-2, and TNF- $\alpha$ expression at the transcriptional level (Fig 5B). We confirmed that AEOJ was capable of attenuating LPS-induced inflammatory mediators via the inhibition of NF-KB activation.

(A)

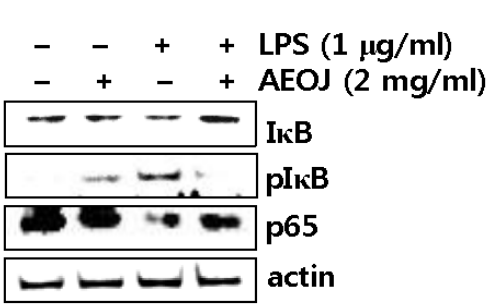

(B)

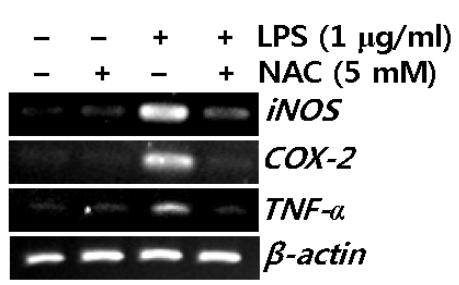

Figure 5: Effect of AEOJ on IKBa degradation, IKBa phosphorylation and p65 protein expression in LPSstimulated RAW 264.7 cells. (A) Cells were preincubated with AEOJ $(2.0 \mathrm{mg} / \mathrm{ml})$ for $1 \mathrm{~h}$ before stimulation with LPS $(1.0 \mu \mathrm{g} / \mathrm{ml})$ for $30 \mathrm{~min}$. Cytoplasmic extracts were then prepared to determine the levels of $1 \kappa B \alpha, p-I \kappa B a$, and p65 by Western blot analysis. (B) In a parallel experiment, cells were pretreated with $5 \mathrm{mM}$ NAC for $1 \mathrm{~h}$ before treatment with LPS for $24 \mathrm{~h}$. Total RNA was isolated, and RT-PCR was performed. $\beta$-Actin was used as an internal control for Western blot analysis and RTPCR. The experiment was carried out in triplicate, and the mean was taken. 


\section{DISCUSSION}

Although AEOJ has been used traditionally for the treatment of cough, arthritis, dysentery and malaria in Asia [1-3], little is known about the molecular mechanisms underlying its anti-inflammatory activities. In the present study, we showed that AEOJ remarkably attenuated the expression of inflammatory gene products such as iNOS, COX-2, and TNF- $\alpha$ at the protein and mRNA levels through the NF-KB pathway.

It is well known that $\mathrm{NO}$ and $\mathrm{PGE}_{2}$ are the main macrophage-derived inflammatory mediators [20-21]. Furthermore, it has been reported that TNF- $\alpha$ is an inflammatory cytokine, which is considered as an endogenous mediator in LPS-induced shock [22]. Aberrant production of $\mathrm{NO}, \mathrm{PGE}_{2}$, and TNF- $\alpha$ induces an inflammatory response that causes damage to neighboring cells and tissues of the host. Therefore, it has been thought a good strategy to reduce LPSinduced inflammation through the suppression of these inflammatory mediators. Among the overproduced inflammatory mediators, NO has been strongly implicated in the pathogenesis of several disease processes such as septic shock, rheumatoid arthritis, and autoimmune diabetes [23]. Furthermore, $\mathrm{PGE}_{2}$ and TNF- $\alpha$ are highly detectable in the serum after induction by pro-inflammatory responses, which are implied in the pathogenesis of sepsis and inflammation $[24,25]$. According to the results of the present study, AEOJ suppressed the production of NO, PGE 2 , and TNF- $\alpha$ in LPSstimulated RAW 264.7 cells via the regulation of transcriptional expression. The mechanism by which AEOJ inhibits the expression of these gene products seems to involve the regulation of the common transcription factor.

NF-kB is present in the cytoplasm as an inactivated dimer composed of p65 and p50 subunits. In response to inflammatory stimuli, IKB is phosphorylated and degraded, and NF$\mathrm{KB}$ is released and translocated into the nucleus [26]. Because the expression of many inflammatory genes, including iNOS, COX-2, and TNF- $\alpha$, are known to be modulated by the binding of NF-KB to its specific promoter regions [27], it is a good target for suppressing NF-kB activity for the regulation of LPS-induced inflammation. Our results showed that AEOJ decreases LPSinduced phosphorylation of $\mathrm{IKB}$ and the resultant degradation of the IKB protein. It also helped sustain the expression of the p65 protein in the cytoplasm. Pretreatment of cells with AEOJ suppressed this signal; this finding suggests that AEOJ inhibits NF-KB activation via inhibition of $\mathrm{K} B$ phosphorylation. Taken together, these results suggest that AEOJ inhibits LPSinduced NF-KB activity by suppressing the degradation and phosphorylation of IKB. However, we can-not rule out the possibility that the inflammatory response is attenuated via the inhibition of other transcription factors.

\section{CONCLUSION}

This study confirmed that AEOJ has antiinflammatory effects, via the suppression of NF-KB activation in RAW 264.7 cells, thereby suppressing the release of $\mathrm{NO}, \mathrm{PGE}_{2}$, and TNF- $\alpha$. Therefore, understanding the mechanism of AEOJ action may lead to the development of more effective therapies for LPS-induced inflammatory diseases.

\section{ACKNOWLEDGMENT}

This study was carried out under the auspices of a grant from Jeju National University, Jeju Republic of Korea.

\section{REFERENCES}

1. Funayama $S$, Tanaka $R$, Kumekawa $Y$, Noshita $T$, Mori T, Kashiwagura T, Murata K. Rat small intestine muscle relaxation alkaloids from Orixa japonica leaves. Biol Pharm Bull 2001; 24: 100-102.

2. Noshita $T$, Tando $M$, Suzuki $K$, Murata $K$, Funayama $S$. New quinoline alkaloids from the leaves and stems of Orixa japonica, orijanone, isopteleflorine and 3'-O-methylorixine. Biosci Biotechnol Biochem 2001; 65: 710-713. 
3. Ono $H$, Nishida $R$, Kuwahara Y. A dihydroxygamma-lactone as an oviposition stimulant for the swallowtail butterfly, Papilio bianor, from the rutaceous plant, Orixa japonica. Biosci Biotechnol Biochem 2000; 64: 1970-1973.I

4. Sharma N, Sharma VK, Seo SY. Screening of some medicinal plants for anti-lipase activity. $J$ Ethnopharmacol 2005; 97: 453-456.

5. Kim SS, Kim JY, Lee NH, Hyun CG. Antibacterial and anti-inflammatory effects of Jeju medicinal plants against acne-inducing bacteria. J Gen

6. Good PF, Hsu A, Werner P, Perl DP, Olanow CW. Protein nitration in Parkinson's disease. $J$ Neuropathol Exp Neurol 1998; 57: 338-342.

7. ladecola $C$, Zhang $F$, Casey $R$, Nagayama $M$, Ross $M E$. Delayed reduction of ischemic brain injury and neurological deficits in mice lacking the inducible nitric oxide synthase gene. J Neurosci 1997; 17: 9157-9164.

8. Amin AR, Attur M, Abramson SB. Nitric oxide synthase and cyclooxygenases: distribution, regulation, and intervention in arthritis. Curr

9. $Y u H H, W u F L$, Lin SE, Shen LJ. Recombinant arginine deiminase reduces inducible nitric oxide synthase iNOS-mediated neurotoxicity in a coculture of neurons and microglia. $J$ Neurosci Res 2008; 86: 2963-2972.

10. McCoy JM, Wicks JR, Audoly LP. The role of prostaglandin $E_{2}$ receptors in the pathogenesis of rheumatoid arthritis. J Clin Invest 2002; 110: 651-658

11. Vancheri C, Mastruzzo C, Sortino MA, Crimi N. The lung as a privileged site for the beneficial actions of $\mathrm{PGE}_{2}$. Trends Immunol 2004; 25: 40-46.

12. Hseu YC, Wu FY, Wu JJ, Chen JY, Chang WH, Lu FJ, Lai YC, Yang HL. Anti-inflammatory potential of Antrodia camphorata through inhibition of iNOS, COX-2 and cytokines via the NF-kB pathway. Int Immunopharmacol 2005; 5: 1914-1925.

13. Garlanda C, Di Liberto DD, Vecchi A, Manna MP, Buracchi C, Caccamo N, Salerno A, Dieli F, Mantovani A. Damping excessive inflammation and tissue damage in mycobacterium tuberculosis infection by toll IL-1 receptor 8/single Ig IL-1-related receptor, a negative regulator of IL-1/TLR signaling. J Immunol 2007; 179: 3119-3127.

14. Ghosh S, Karin M. Missing pieces in the NF-KB puzzle. Cell 2002; 109: 81-96.
15. Bonizzi G, Karin M. The two NF-KB activation pathways and their role in innate and adaptive immunity. Trends Immunol 2004; 25: 280-288

16. Hayden MS, Ghosh S. Signaling to NF-kB. Gene Dev 2004; 15:2195-224.

17. Jimi E, Ghosh S. Role of nuclear factor-kappaB in the immune system and bone. Immunol Rev 2005; 208: 80-87.

18. Baeuerle PA, Baichwal VR. NF-KB as a frequent target for immunosuppressive and antiinflammatory molecules. Adv Immunol 1997; 65:.111-137.

19. Shishodia S, Aggarwal BB. Nuclear factor-KB activation: a question of life and death. $J$ Biochem Mol Biol 2002; 35: 28-40.

20. Vodovotz Y, Kim PK, Bagci EZ, Ermentrout GB, Chow CC, Bahar I, Billiar TR. Inflammatory modulation of hepatocyte apoptosis by nitric oxide: in vivo, in vitro, and in silico studies. Curr Mol Med 2004; 4: 753-762.

21. Moncada S, Higgs EA. Nitric oxide and the vascular endothelium. Handb Exp Pharmacol 2006; 176: 213-254.

22. Dinarello CA. Cytokines as endogenous pyrogens. $J$ Infect Dis 1999; 179: 294-304.

23. Stuehr DJ, Marletta MA. Synthesis of nitrite and nitrate in murine macrophage cell lines. Cancer Res 1987; 47: 5590-5594.

24. Geng $Y$, Zhang B, Lotz $M$. Protein tyrosine kinase activation if required for lipopolysaccharide induction of cytokines in human blood monocytes. J Immunol 1993; 151: 6692-6700.

25. Harris SG, Padilla J, Koumas L, Ray D, Phipps RP. Prostaglandins as modulators of immunity. Trends Immunol 2002; 23: 144-150.

26. Schottelius AJ, Baldwin AS (Jr). A role for transcription factor NF-KB in intestinal inflammation. Int J Colorectal Dis 1999; 14: 601-609.

27. Baima ET, Guzova JA, Mathialagan S, Nagiec EE, Hardy MM, Song LR, Bonar SL, Weinberg RA, Selness SR, Woodard SS, Chrencik J, Hood WF, Schindler JF, Kishore N, Mbalaviele G. Novel insights into the cellular mechanisms of the anti-inflammatory effects of NF-KB essential modulator binding domain peptides. J Biol Chem 2010; 285: 13498-13506. 